UDC: 34.096

DOI: https://doi.org/10.24195/2414-4665-2017-6-22

Sergii Pavlenko
PhD (Candidate of Law), leading researcher,
Department of Organization of Research Work,
Volodymyr Sevruk,
PhD (Candidate of Law), leading researcher,
Department of Organization of Research Work,

Yevhen Kobko,

PhD (Candidate of Law), associate professor, Department of Administrative Law and Process, National Academy of Internal Affairs, 1, Solomianska Square, Kyiv, Ukraine

\title{
TRAINING POLICE OFFICERS IN THE CONDITIONS OF REFORMING THE SYSTEM OF EDUCATION OF THE MINISTRY OF INTERNAL AFFAIRS OF UKRAINE IN ACCORDANCE WITH EUROPEAN STANDARDS
}

The paper deals with relevant issues of the transformation of Ukrainian law enforcement institutions of higher education according to modern European models and concepts of training police officers. In determining the purpose of police education, the most controversial issue is whether to provide police officers with high-grade education or to train functional specialists in specific areas of police activity. The system of police training in Schengen countries is different and noticeable for the lack of a single unified approach because of a wide range of teaching concepts. Foreign experience and advanced practice in law-enforcement education can become an ideological platform in the course of Ukrainian reforms. However, excessive attempts to transfer the experience of foreign systems of training police officers to Ukrainian reality are not justified, because national characteristics, educational traditions and positive results in this area are usually ignored. Therefore, the standards established in the legal systems of other countries should be combined with verified domestic developments in education. The police training based on curriculum of legal education and the degrees of Bachelor and Master is the accomplishment of domestic law enforcement system of Ukraine. Therefore, in the process of developing the Concept aimed at improving the legal (judicial) education for jurist's professional training according to EU standards, special attention should be paid to law schools with specific learning environments taking into account that one of the main tasks of the police is to protect human rights and freedoms, as well as interests of society and the state.

Keywords: training, law enforcement institutions, reformation, police, education.

\section{Introduction}

At the present stage of state building, Ukraine's integration into the European Union is seen as an essential in further democratization of our country and the formation of civil society [1, p. 52]. Therefore, over the last decade, the radical socio-economic transformations have caused both positive and negative changes in the modern Ukrainian society. Primarily, it concerns training police officers in the conditions of reforming the educational system of the Ministry of Internal Affairs of Ukraine in accordance with European standards.

Education in higher educational institutions of the Ministry of Internal Affairs of Ukraine has always been an important and integral part of the training police staff, while its formation and development have taken place under imperfect conditions of state building in independent Ukraine. The issue of insufficient financial resources, periodic neglect of social security for workers, the lack of proper material and technical support and normalized conditions of work have caused a significant outflow of highly skilled workers in other areas of legal activity, and consequently, the destruction of the value system $[2, \mathrm{p}$. 52].

The poll conducted according to the order of the Minister of Internal Affairs of Ukraine (dated June 03, 2015, No. 23312 / Av) confirmed the above mentioned statements. The research has demonstrated that the effectiveness of the system of law enforcement bodies depends to a large extent on solving such problems as: low monetary security $-82.7 \%$; bad technical support of service activity $-57.6 \%$; drawbacks of procedural legislation $44.8 \%$; dismissal of workers with experience of work $36.8 \%$; drawbacks of criminal legislation $-27.1 \%$; disadvantages of administrative legislation $-23.2 \%$, etc. [3].

In modern society, a police officer should be of high cultural, educational development, self-educational and self-improvement ability, and able to apply his/her knowledge in various areas of law enforcement that ob- 
jectively requires rethinking of the existing police training system [4]. Therefore, professionalism, proper police officers' training is the main and leading factor in ensuring the safety of the life of police staff and population [5].

At the present stage of state building, the primary ways of the development of departmental education have been covered by such domestic scientists, as S. Alforov, T. Hrytsia, I. Zozulia, O. Korystin, V. Len, M. Loshytskyi, D. Poshtaruk, S. Tsyhanii, V. Cherniei, S. Cherniavskyi and others. At the same time, with the entry into force of the Laws of Ukraine "On Higher Education" dated July 1, 2014, No. 1556-VII, "On the National Police" dated July 2, 2015, 580-VIII, the role of the departmental education in the national legal system has regained its significance. This process is objective and conditioned by certain trends in training law enforcement officers [6].

The aim of the article is to elucidate the priorities of reforming the education system of the Ministry of Internal Affairs of Ukraine in accordance with European standards.

\section{Research methods}

The study has been carried out based on theoretical methods of research (theoretical analysis, synthesis, induction, comparison, generalization, systematization), as well as empirical ones (surveys; statistics).

\section{Discussion}

Regarding the outlook of activity of the higher educational institutions related to the Ministry of Internal Affairs of Ukraine, as well as their place and role in reforming the law-enforcement system, their departmental affiliation is conceptual. There are two main viewpoints on this issue. The followers of the first favor the subordination of the higher educational institutions of the Ministry of Internal Affairs of Ukraine to the very Ministry, while others support transferring them to the management of the Ministry of Education and Science of Ukraine with the appropriate change in funding and the status of participants in the educational process [7, p. 27].

Some researchers [8] note that the system of training at the higher educational institutions of the Ministry of Internal Affairs of Ukraine is outdated and contributes to corruption and excessive spending of budget funds. They give a rationale for this position emphasizing that one of the primary ways of successful reformation of police education is the complete elimination of the higher educational institutions of the Ministry of Internal Affairs of Ukraine.

According to this group of researchers, state and private civil universities can become the alternative solution of this issue. Moreover, using the comparative analysis of legal educational systems in departmental and civil institutions, it has been concluded that in its content the law profession training slightly differs from each other.

However, the decisive difference is that, unlike civil universities, the majority of teachers at the higher educational institutions of the Ministry of Internal Affairs are police officers who, in accordance with the current legislation, enjoy benefits and social guarantees the same as investigators and operational staff that, in turn, leads to excessive spending of budget funds.

On the contrary, the analysis of such perspective issues on the ways of reforming police education seems debatable; therefore, we provide several arguments in opposition to such considerations.

1. With regard to the elimination of all higher educational institutions of the Ministry of Internal Affairs, a commonly known proverb "It is easier to pull down than to build" is considered to be appropriate because destroying something is not a great merit. It is much harder to create.

Therefore, we agree with the scholars $[7 ; 9]$ who argue that the implementation of any radical measures for the reorganization of educational institutions of departmental subordination seems premature, especially while the work on the creation of a new concept for training law enforcers as an integral part of a comprehensive program for reforming the law enforcement system is incomplete. Such actions create risks of unpredictable negative consequences, which may be detrimental to updating the legal system of the Ukrainian state.

On the contrary, an important resource of the national legal system of Ukraine is its scientific potential, the formation of which is facilitated by fundamental and applied researches in law, conducted by academic institutions, branch research centers, higher educational institutions, research groups, and individual scientists [10].

The most prominent representatives of the established schools of higher education of the Ministry of Internal Affairs of Ukraine are academicians, doctors of legal sciences, professors, and scholars with worldwide recognition such as V.V. Kopieichykov, P.P. Mykhailenko, A.P. Zakaliuk, Yu.I. Rymarenko, I.P. Kozachenko, V.P. Bakhin, M.V. Kostytskyi, M.V. Saltevskyi and others, who have contributed to the development of departmental education and science.

Implementing scientific interests, their students and followers have expanded the scientific and methodological as well as educational and methodical basis of educational activity in jurisprudence entirely. Furthermore, practical law-enforcement activities have been contributed with a huge array of scientific and educational developments and materials. Scientific research and educational materials have not go beyond any law-enforcement sphere and formed a solid scientific and methodological basis for the implementation of law enforcement functions in our country [4].

2. As regards training law-enforcement officersjurists by state and private civil higher educational institutions, in 2002, professor V.S. Venediktov spoke about the difference in training specialists at the departmental (of the Ministry of Internal Affairs of Ukraine) and civil educational institutions, which train specialists in law for the Ministry of Internal Affairs, because the latter demonstrate absolute insolvency to provide training of the appropriate professional level and quality [11, p. 378]. 
Therefore, current legal educational system, introduced in civil educational institutions, is not suitable for training specialists for working in the National Police (NP) of Ukraine for the following reasons:

1. Civil educational establishments are not aimed at training specialists specifically for the National Police of Ukraine and, consequently, do not take into account the specifics of the activity of this executive body. They mostly train multi-skilled specialists majoring in Law.

2. Despite the specifics of the jurist's professional training due to the special content of their work, admission to the full-time course to law departments and law faculty does not differ from admission to other faculties or other higher educational institutions. The main criterion for selecting potential specialists in law is the successful results of external independent testing. It is undoubtedly crucial but its application does not reveal such necessary qualities for the future employee of the NP of Ukraine as honesty, morality, invincibility and psychological endurance. In the documents submitted by the entrant, these qualities are not reflected properly. The disadvantages of the current admission rules are confirmed by the crimes and other offenses committed by students, as well as by the enrollment of persons related to the criminal environment before.

3. In civil educational institutions educational programs do not sufficiently take into account practical training, give preference to the theory and are separated from actual practice. Educational programs do not include such necessary for the future law enforcement officer disciplines as "Combat training", "Operative and search activity", "Special equipment", "OSpecial tactics". Even physical training at law faculties and higher law institutions is carried out according to a general program that does not take into account the specifics of the NP of Ukraine.

4. Not all students of juridical faculties and higher law institutions can undergo an internship in the bodies of the Ukrainian National Policy. Even for students of higher law schools majoring in Law the internship takes a rather short term, besides, practitioners are not interested in guiding the students of civil educational institutions.

5. Some of the civil educational institutions have full-time and part-time forms of training. Nevertheless, training an investigator, operational staff and other specialists requires consideration of the specifics of their activities.

6. Civil education institutions graduate specialists, who mostly are not able to adapt to practical subdivision after graduation and carry out their duties effectively. They need time to get prepared for practical work $[9, \mathrm{p}$. 56-57].

Therefore, in contrast to many other civil higher educational institutions, departmental institutions of higher education of the Ministry of Internal Affairs (MIA) not only provide theoretical training, but also permanently work hard on practical law enforcement officers' training, who will represent the MIA of Ukraine in the near future and ensure efficient operation of all its agencies and departments [12, p. 436].

Moreover, practitioners [13, p. 337], [14], [15] indicate that the quality of knowledge and practical skills of graduates of some civil institutions of higher legal education do not meet the real requirements of their future work. In transforming modern legal system of Ukraine, experts identify such crucial issues of legal education as: inconsistency of the system of legal education to the real needs of the society and state; controversy and uncertainty concerning the content of legal education standard; urgent need to improve its quality; complex processes of internationalization and integration of higher legal education into European and world educational spaces; reduction of legal culture and legal education of entrants; inheritance and, to a certain extent, preservation of the Soviet system of theoretical and jurists' practical training, which is manifested in distorted corporate identity of the profession of a jurist, etc. [14], [15].

Furthermore, in this area one of the issues is the lack of jurist's practical training. For the reason that graduates of civil law universities often lack practical skills, they cannot work on specialty immediately after graduation [16. p. 22].

Despite such a situation, in some civil higher educational institutions and ones of the Ministry of Internal Affairs there are legal clinics, in which cadets and students under the guidance of a teacher-curator provide free legal advice to the population (that contributes to the credibility of the institution and the Ministry of Internal Affairs in general, become the school of legal practice and an effective means of vocational guidance). Evidently, in the legal clinic, students and cadets receive certain legal practical skills and comprehend what people need and how they can protect their rights legally. Thus, students and cadets are actively involved in formulating responses to client's requests and develop their professional competence.

In addition, there are a great number of higher educational institutions of different forms of ownership in Ukraine which train jurists. As a result, the quality of the education of graduators is reducing as they the institutions provide education to everyone interested in the specialty "Law".

The statement is confirmed by a survey of practicing lawyers conducted by the Association of Ukrainian Lawyers, according to which only $16.6 \%$ of the respondents believe that modern legal education is able to provide high-quality service. On the contrary, $50.7 \%$ of the respondents consider it to be "satisfactory". The rest of the respondents consider the status of legal education in Ukraine to be poor (26.8\%), and even very bad (7\%) [17].

Therefore, in many higher educational institutions of Ukraine, the existing system of training legal professions needs serious reformation, because it does not adequately ensure future lawyers' proper training. 
3. As for the teachers of higher educational institutions the Ministry of Internal Affairs, we believe that their status of police officers is quite a positive aspect. In any case, all teachers with special ranks have practical experience in the bodies of the National Police of Ukraine. In this regard, Boetius of Dacia's statement comes to mind: "If the one has never been a student, will not ever be a teacher".

Therefore, it is reasonable to suggest that a future doctor should be trained by a doctor, and a future policeman should be trained by a policeman. In addition, practical activities of teachers provide cadets and students with the necessary life experience in the period of training.

Moreover, it is unclear how the teacher of a civil university without practical experience in law enforcement bodies and without specific knowledge will provide training for cadets concerning the disclosure and investigation of crimes (specifics of documenting organized criminal groups or tactical specifics of questioning leaders and members of organized criminal groups, etc.)

Furthermore, it remains unclear how the status of a teacher-policeman, who uses social security benefits, will affect budget. In this regard, prevention of corruption in high places seems to be a more effective means of saving the state "treasury". Indeed, the Law of Ukraine "On National Police" states the social protection of the police, as well as the financial and logistical support of the police. Despite this, the existing social welfare legislation needs to be revised, taking into account not only international standards but also the legal and economic realities of the present (in particular, decent wages, provision of free rental housing at the expense of budget funds, introduction of decent monetary compensation for participation in antiterrorist operations, etc.) [18, p. 270].

We believe that international cooperation is an indicator of the development of universities. For example, the higher educational institutions of the Ministry of Internal Affairs successfully cooperate with such reputable international non-governmental organizations as the Association of Higher Educational Institutions of the Ministry of Internal Affairs / Police of the CIS member states, the Association of European Police Colleges, which, in turn, organize internship programs for scientific and pedagogical staff, listeners and cadets abroad, which enable active learning from training police officers in European countries and the USA.

For example, the National Academy of Internal Affairs is a participant of 30 protocols on international cooperation. There has been supported its expansion with five more countries, non-governmental organizations of Great Britain, France, Germany, Moldova, the Baltic States, as well as the USA. Thematic seminars with experts from influential international organizations with a participation of 120 foreign representatives took place in a wide format. Implementation of international obligations on training peacekeeping forces of civilian police of the UN, OSCE and EU, which now represent the Ministry of Internal Affairs of Ukraine in other countries, is one of the specific task [19].

To sum up, in Ukraine training police officers based on the curriculum of legal education and the educational level of bachelor, master is the accomplishment of national law enforcement system, and not vice versa. Modern society is characterized by global integration changes in economic, socio-cultural, informational interaction that influences reforming of educational sector. The departmental police training system is no exception in improving within the framework of domestic education together with active reformation of the Ministry of Internal Affairs itself.

Therefore, the Ukrainian state has some experience in law enforcement, and this experience assures solving the challenges posed by modern reforms. At the same time, the course to the European community taken by the state obliges to investigate the world experience of police training [20, p. 289].

For example, all UK police officers start their careers with an 18-week stationary training course at a specialized police college. After a successful completion, recruits are transferred to the police station, where they undergo the remaining two-year approbation. Together with experienced colleagues, they are involved in patrolling streets, learning to make contact with people, evaluating the situation and making quick accurate decisions. Throughout the testing period, their professional growth is assessed and senior officers provide them with support and instruction. After completion of the probationary period, the recruits receive the rank of a police constable [21].

In the US, higher education for police is focused on trying to figure out whether higher education helps law enforcement officials improve the quality of police service. This issue is examined from both the theoretical and practical perspective to determine the level of professionalism and validity to increase the proportion of universities and colleges graduates to create a highly efficient and functioning of police departments. The Police Leadership Research Forum conducted an analysis of the level of education and training recruits, who come to the service. According to the results of the survey, $94.8 \%$ police departments have educational standards, of which more than $50 \%$ require a certificate of maturity (secondary education), 27\% - a diploma of two-year college and 5\% - a Bachelor's degree [22].

Therefore, police work as a profession should be defined. In most studies, the police is characterized as a system of humane and constitutional application of legitimate authority in the interests of citizens, based on the principles of trust, altruism and the commonwealth, and operates according to high ethical standards [23].

However, training police officers in the countriesparticipants of the Schengen agreement is different with specific features, without single methodological approach due to various educational ideologies. 
European countries have quite different systems of police education and training. Nowadays, all EU countries have educational institutions that train professional police officers. Police academies are created on the basis of the Ministries of Internal Affairs of the country or under its patronage on the basis of higher education institutions as a separate department. In educational institutions, great attention is paid not only to the basic skills of policemen (criminalistics, investigative actions, forensic medical examination, etc.), but also such general public subjects as sociology, political science, psychology, foreign languages, which equals the training of a policeman and education in a vocational institution.

Basic training for police officers (Bachelor of Police) takes from three to four years, and then regular maintenance of efficiency by professional training and exercises is mandatory. The Master of Police level for senior management positions in the authorities takes one to two years of postgraduate education. It is also possible to master the police profession by a shortened procedure in case of having graduation level of higher education, when it takes about two years of training focused on acquiring practical skills for work in the police service.

The entire policemen training is usually divided into three types:

- basic training comprises learning the basic skills to perform police functions (driving, arrest criminals, law, etc.).

- specialized training is additional training in various areas of police activity (criminal prosecution, work with minors, negotiation, etc.).

- staff training is a series of trainings provided for senior police officers, who are responsible for the work of other police officers.

The laws On the Ministry of Internal Affairs and the law "On Higher Education" of the EU member states govern legislation of the police academies. In addition, the regulation is due to the internal statute Police Academy and single acts of the Ministry of Internal Affairs [24].

Considering the above, every country has its own unique system of training relevant experts for police, designed under the influence of territorial, historical, political, social and economic factors and different national legal systems.

It should be noted that in a number of European countries educational institutions are within the national education system, where police training is carried out on the basis of general state standards of professional education. In other countries, training police officers (with the exception of senior staff) is focused on narrow professional police training $[25$, p. 38$]$.

In developed countries, among certain achievements of police education there are high technical equipment, the applicability of the educational process and research, the study of concrete work, the development of skills and abilities (often exercised to automatism). There specialists are trained in specific areas of activity, adapted to real conditions. The universities of the Ministry of Internal Affairs of Ukraine should strive for such standard.

However, foreign general education, theoretical training, ideological issues are to a certain extent inferior to the domestic one. Nevertheless, this cannot be considered as a disadvantage to overcome. In departmental education, many positions are worth achieving the western level, but there are many domestic accomplishments to be kept, multiplied, proud of and improved [26, p. 378].

Primarily, it concerns practicing not only in the bodies of the National Police of Ukraine, but also in court. This will facilitate better training of investigators and operational staff. Particularly, cadets taking internship will develop their own vision, understanding of the attitude of judges to their duties, their cooperation with prosecutors, investigators, and the role of a lawyer in the trial. Moreover, the cadets will realize the importance of the profession chosen [27, p. 28].

The profession of a policeman is one of the most complex in the modern society, since it requires a person to be able to deal with professional tasks risky to life, quickly react to a particular situation with a high level of responsibility for his/her actions.

Therefore, while developing the Concept for the improvement of legal (judicial) education for the professional jurists' training in accordance with European standards of higher education and the legal profession, special attention should be paid to law schools with specific learning environments, considering the police task to protect human rights and freedoms, as well as the interests of society and the state as primary one.

\section{Conclusions}

To conclude, the experience of other countries regarding the training and education of police officers can be a guiding factor in reforming the system of higher educational institutions of the Ministry of Internal Affairs of Ukraine. However, the excessive attention and efforts to transfer the experience of foreign systems of training and education of police officers to Ukraine are not justified because usually our national characteristics, educational traditions and positive results in this area are ignored. Thereby, it is important to combine the standards established in the legal systems of other countries with proven practice of domestic developments in the educational process. The education system of the Ministry of Internal Affairs of Ukraine is not perfect today. However, it has gained considerable positive experience throughout the period of its existence. Therefore, the analysis of strengths and weaknesses of the national departmental education enables to state that at present it requires constant improvement and development, and accordingly hard systematic work on errors to achieve effective and efficient results. Finally, let us remember the words of Taras Shevchenko, "And to your neighbors' gifts pay heed - yet do not thus neglect your own!" 


\section{REFERENCES}

1. Medvedev, Yu. L. (2014). Nablyzhennia prava Ukrainy do prava Yevropeyskoho soyuzu: poniatiinokatehorialnyi aparat ta sposoby uz hodzhennia [Approximation of the law of Ukraine to the right of the European Union: conceptual-categorical apparatus and methods of harmonization]. Visnyk Luhanskoho derzhavnoho universytetu vnutrishnikh sprav imeni E.O. Didorenka - Bulletin of E.O. Didorenka's Luhansk State University of Internal Affairs, 1, 52-59 [in Ukrainian].

2. Rudyi, N. Ya. (2015). Reformuvannia vidomchoi osvity MVS Ukrainy yak skladova polityka natsionalnoi bezpeky u pravookhoronnii sferi [Reforming of departmental education of the Ministry of Internal Affairs of Ukraine as a component of the national security policy in the law-enforcement]. Naukovyi visnyk Lvivskoho derzhavnoho universytetu vnutrishnikh sprav - Scientific Bulletin of E.O. Didorenka's Luhansk State University of Internal Affairs, 3, 51-57 [in Ukrainian].

3. Naukovo-analitychnyi ohliad rezultativ sotsiolohichnoho opytuvannia pratsivnykiv OVS ta slukhachiv vyshchykh navchalnykh zakladiv OVS u 2015 rotsi [Scientific and analytical review of the results of a sociological survey of employees of law enforcement bodies and students of higher education institutions of law enforcement bodies in 2015]. Retrieved from: http://mvs.gov.ua/upload/file/soc_olog_chne_opituvannia _atestovanih_prac_vnik_v_m_1_c.pdf. [in Ukrainian].

4. Korystin, O. Ye. (n. d.). Profesiina osvita politseyskoho: $v$ yakomu napriami rukhatys [Professional education of a policeman: what way to choose]. Retrieved from: http://www.vestnik-ua.com/politika/item/3887profesijna-osvita-politsejskogo-v-yakomu-napryamkurukhatis. [in Ukrainian].

5. Kontseptualni osnovy do reformuvannia orhaniv vnutrishnikh sprav yak skladovoi pravookhoronnoi systemy ta sektoru bezpeky i oborony Ukrainy [Conceptual bases for reforming Internal Affairs bodies as a component of the law-enforcement system and the security and defense sector of Ukraine]. Kontseptualni pidkhody do reformuvannia MVS u konteksti zahalnonatsionalnoho planu reform: informatsiino-analitychni materialy kruhloho stolu vid 16 kvitnia 2015r - Conceptual approaches to the reform of the Ministry of Internal Affairs in the context of the national reform plan: informational and analytical materials of the round table of April 16, 2015. Kyiv [in Ukrainian].

6. Zakon Ukrainy "Pro vyshchu osvitu" [The Law of Ukraine “On Higher Education”]. (2014, July 01), no. 1556-VII. Retrieved from: http://zakon2.rada.gov.ua/laws/show/1556-18 (Amended on March 05, 2017, on the base 1838-19). [in Ukrainian].

7. Alforov, S. M. (2014). Perspektyvy rozvytku vidomchykh VNZ MVS Ukrainy u konteksti vprovadzhennia novoho Zakonu Ukrainy «Pro vyshchu osvitu» [Prospects for the development of departmental higher educational institutions of the Ministry of Internal Affairs of Ukraine in the context of the introduction of the new
Law of Ukraine "On Higher Education"]. Kharkivskyi natsionalnyi universytet vnutrishnikh sprav $v$ systemi pidhotovky kadriv Ukrainy: materialy Vseukr. nauk.prakt. konf., 26 veres. 2014 r. - Kharkiv National University of Internal Affairs in the system of personnel training Ukraine: materials Ukr. Sci. Pract. Conf., Sept. 26, 2014, (pp. 27-29). Ministry of Internal Affairs of Ukraine, Kharkiv National University of Internal Affairs. Kharkiv: KhNUVS [in Ukrainian].

8. Malyshev, B. (n. d.). Chomu reforma politseyskoi osvity neobkhidna ta yak yii zdiisnyty [The need of the police education reform and the ways of implementation]. Retrieved from: http://policeexperts.info/2016/09/22/police_education_1/. [in Ukrainian].

9. Hrytsia, T. H. (2002). Znachennia vidomchoi osvity dlia pidhotovky pratsivnykiv OVS Ukrainy [The value of departmental education for training officers of the Ministry of Internal Affairs of Ukraine]. Pravo $i$ bezpeka-Low and safety, 4, 55-59 [in Ukrainian].

10. Pasmor, Yu. V. (2010). Naukovi doslidzhennia v haluzi prava yak obiekt informatsiinoho zabezpechennia [Scientific research in law as an object of information support]. Visnyk Kharkivskoi derzhavnoi akademiii arkhitektury - Bulletin of the Kharkiv State Academy of Architecture, 30 [in Ukrainian].

11. Zozulia, I. V. (2008). Teoriia i praktyka reformuvannia systemy MVS Ukrainy: monohrafiia [Theory and practice of reforming the system of the Ministry of Internal Affairs of Ukraine: monography]. Kharkiv: Kharkiv yurydychnyi [in Ukrainian].

12. Poshtaruk, D. O. Vdoskonalennia chynnoho polozhennia pro vyshchi navchalni zaklady MVS [Improvement of the current statement on Higher Educational Institutions of the Ministry of Internal Affairs]. Forum prava -Law Forum. Retrieved from: file:///C:/Users/Serg/Downloads/FP_index.htm_2013_2_7 2.pdf. [in Ukrainian].

13. Kalintseva, O. V. (2016). Protses fakhovoi pidhotovky yurystiv yak pedahohichna problema [Lawyers' professional training as a pedagogical problem]. Molodyi vchenyi - Young scientist, 8 (35), 337-341 [in Ukrainian].

14. Stetsyuk, L. O. Problemy vyshchoi yurydychnoi osvity ta shliakhy yikh vyrishennia [Issues of higher legal education and ways of their solution]. Retrieved from: http://irbisnbuv.gov.ua/cgi-bin/irbis_ nbuv; [in Ukrainian].

15. Krupchan O. D. (2013) Do pytannia pro yakist yurydychnoi osvity [On the issue of the quality of legal education]. Pravove rehulyuvannia ekonomiky - The legal regulation of the economy, 13, 48-52 [in Ukrainian].

16. Sushchenko, V. M. (2007). Suchasni problemy reformuvannia yurydychnoi osvity i nauky $\mathrm{v}$ Ukraini [Modern problems of reforming legal education and science in Ukraine]. Naukovi pratsi. Nauk.-metod. zhurnal. Politychni nauky. Pravoznavstvo - Scientific papers. 
Scientific methodological magazine. Political science. Science of law, 69, 184-187 [in Ukrainian].

17. Hubanova, T. O. (2016). Osnovni problemy praktychnoi fakhovoi pidhotovky yurystiv u koledzhakh yak haluzevykh vyshchykh navchalnykh zakladakh Ukrainy [The main issues of lawyers' practical training in colleges as departmental higher educational institutions of Ukraine]. Porivnialno-analitychne pravo - Comparative and analytical law, 4, 21-24 [in Ukrainian].

18. Pashkovska, T. Yurosvita v Ukraini: pravnyky dorikaiut na nedopratsiuvannia [Legal education in Ukraine: lawyers complain about misunderstanding]. Yurydychna Hazeta online - Legal Newspaper online. Retrieved from: http://yurgazeta.com/publications/events/yurosvita-v-ukrainipravniki-dorikayut-na-nedopracyuvannia.html.

[in Ukrainian].

19. Inshyn, M. I. (2015). Sutnist i znachennia sotsialnoho zabezpechennia pratsivnykiv politsiii $v$ suchasnykh umovakh [The essence and meaning of social security for police officers in modern conditions]. Visnyk Chernivetskoho fakultetu Natsionalnoho universytetu «Odeska yurydychna akademiia» - Bulletin of the Chernivtsi Faculty of the National University "Odessa Law Academy", 4, 268-277 [in Ukrainian].

20. Cherniei, V. V. (2014). Natsionalna akademiia vnutrishnikh sprav u konteksti realizatsii polozhen novoho Zakonu Ukrainy «Pro vyshchu osvitu» [National Academy of Internal Affairs in the context of the implementation of the statements of the new Law of Ukraine "On Higher Education"]. Kharkivskyi natsionalnyi universytet vnutrishnikh sprav $v$ systemi pidhotovky kadriv Ukrainy: materialy Vseukr. nauk.-prakt. konf., 26 veres. 2014 r. - Kharkiv National University of Internal Affairs in the system of personnel training of Ukraine: materials of Ukr. Sci. Pract. Conf. of Sept. 26, 2014. (pp. 22-27). Ministry of Internal Affairs of Ukraine, Kharkiv National University of Internal Affairs. Kharkiv: KhNUVS [in Ukrainian].

21. Chernenko, A. P. (2016). Yevropeisikyi dosvid pidhotovky politseiskykh ta mozhlyvist yoho vykorystannia $\mathrm{v}$ Ukraini [European Experience in Police Training and the Possibility of Its Use in Ukraine]. Svitovyi dosvid pidhotovky kadriv politsii ta yoho vprovadzhennia $v$ Ukraini: mater. Mizhnar. nauk.-prakt. konf. (Dniproterovsk, 17 ber. 2016 r.) - World Experience of Police Training and Implementation in Ukraine: Materials of International Sci. Pract. Conf. (Dnipropetrovsk, March

\section{ЛІТЕРАТУРА}

1. Медведев Ю.Л. Наближення права України до права Європейського союзу: понятійнокатегоріальний апарат та способи узгодження / Ю.Л. Медведев // Вісник Луганського державного університету внутрішніх справ імені Е.О. Дідоренка. 2014. - № 1. - C. 52-59.
17, 2016)]. Dnipropetrovsk: Dnipropetrovsk State University of Internal Affairs [in Ukrainian].

22. Smith, A.T.H. (1997). Public Order Act and the offences against Public Order. London [in English].

23. Jurkanin, T. J. (1998). A Statewide System of In-Service Training. - Springfield, IL: Illinois Law Enforcement Training and Standards Board [in English].

24. Illinois Law Enforcement Executive Institute. (1999) Macomb: Western Illinois University [in English].

25. Parshykova, A. (2016). Protsedury pidhotovky politseskykh v krainakh-chlenakh YES (navchalni zaklady ta prohramy, standarty otsinky, zakonodavche rehuliuvannia) [Police Training in EU Member States (Educational Institutions and Programs, Evaluation Standards, Legislative Regulation)]. Informatsiina dovidka, pidhotovlena Yevropeyskym informatsiino-doslidnytskym tsentrom na zapyt narodnoho deputata Ukrainy. - internet Prohramy USAID «RADA» 2015-2016 p. - Informational note prepared by the European Information Research Center at the request of the people's deputy of Ukraine. - Internet Program of USAID "RADA" of 2015 2016] [in Ukrainian].

26. Rug, M. (2003). Yuridicheskiie predmety v programme obucheniia Vysshey shkoly politsii, sovremennoye sostoianiie, perspektivy razvitiia [Legal subjects in the training program of the Higher Police School: current state, development prospects]. Problemy razvitiia obrazovaniia, yuridicheskoy nauki $i$ praktiki: materialy mezhdunar. nauch.-prakt. konf., posviashch. 45-letiiu Akademii MVD Respubliki Belarus / pod obshch. red. I. I. Basetskogo - Issues of the development of education, legal science and practice: materials of the International Scientific Practical Conf., Dedicated to the 45th anniversary of the Academy of the Ministry of Internal Affairs of the Republic of Belarus. I. I. Basetskii (Ed.). Minsk. [in Russian].

27. Tsyhanii, S.O. Profesiino-pravova pidhotovka politseyskykh $\mathrm{v}$ Ukraini ta $\mathrm{v}$ zarubizhnykh krainakh [Police professional and legal training in Ukraine and in foreign countries]. Retrieved from: http://10176-26346-1SM.pdf. [in Ukrainian].

28. Len, V. V. (2007). Do problemy pidhotovky slidchykh orhaniv vnutrishnikh sprav [Investigators' Training for Internal Affairs bodies]. Problemy profesiinoi pidhotovky slidchykh: mater. nauk.-prakt. konf. (Dnipropetrovsk, DDUVS, 27 kvitnia 2007 r.) - Issues of investigators' training: materials of Sci. Pract. Conf. (Dnipropetrovsk, DUUVS, April 27, 2007). (pp. 27-29) [in Ukrainian].

2. Рудий Н. Я. Реформування відомчої освіти МВС України як складова політика національної безпеки у правоохоронній сфері / Н.Я. Рудий // Науковий вісник Львівського державного університету внутрішніх справ. - 2015. - 3. - С. 51-57.

3. Науково-аналітичний огляд результатів соціологічного опитування працівників ОВС та слухачів 
вищих навчальних закладів ОВС у 2015 році. [Електронний ресурс]. - Режим доступу: http://mvs.gov.ua/upload/file/soc_olog_chne_opituvannya _atestovanih_prac_vnik_v_m_1_c.pdf.

4. Користін О.Є. Професійна освіта поліцейського: в якому напрямі рухатись / О.С. Користін // [Електронний ресурс]. - Режим доступу : http://www.vestnik-ua.com/politika/item/3887-profesijnaosvita-politsejskogo-v-yakomu-napryamku-rukhatis.

5. Концептуальні основи до реформування органів внутрішніх справ як складової правоохоронної системи та сектору безпеки і оборони України // Концептуальні підходи до реформування МВС у контексті загальнонаціонального плану реформ : інформаційно-аналітичні матеріали круглого столу від 16 квітня 2015p.-К.,2015.-С. 56.

6. Про вищу освіту: Закон від 01.07.2014 № 1556-VII [Електронний ресурс]. - Режим доступу: http://zakon2.rada.gov.ua/laws/show/1556-18 (із змінами та доповненнями від 05.03.2017, підстава 1838-19).

7. Алфьоров С.М. Перспективи розвитку відомчих ВНЗ МВС України у контексті впровадження нового Закону України «Про вищу освіту» / C.М. Алфьоров // Харківський національний університет внутрішніх справ в системі підготовки кадрів України : матеріали Всеукр. наук.-практ. конф., 26 верес. 2014 р. / МВС України, Харків. нац. ун-т внутр. справ. - Харків : ХНУВС, 2014. - С. 27-29.

8. Малишев Б. Чому реформа поліцейської освіти необхідна та як іiі здійснити / Б. Малишев // [Електронний ресурс]. - Режим доступу: http://policeexperts.info/2016/09/22/police_education_1/.

9. Гриця Т.Г. Значення відомчої освіти для підготовки працівників ОВС України / Т.Г. Гриця // Право і безпека. - 2002. - 4. - С. 55-59.

10. Пасмор Ю.В. Наукові дослідження в галузі права як об'єкт інформаційного забезпечення / Ю.В. Пасмор // Вісник Харківської державної академії архітектури. - 2010. - Випуск 30.

11. Зозуля І.В. Теорія і практика реформування системи МВС України: монографія / I.В. Зозуля. - Х.: Харків юридичний, 2008. - 480 с.

12. Поштарук Д.О. Вдосконалення чинного положення про вищі навчальні заклади МВС / Д.О. Поштарук // Форум права. [Електронний ресурс]. - Режим доступу: file:///C:/Users/Serg/Downloads/FP_index.htm_2013_2_7 2.pdf.

13. Калінцева О.В. Процес фахової підготовки юристів як педагогічна проблема / О.В. Калінцева // Молодий вчений. - 2016. - № 8 (35). - 337 - 341.

14. Стецюк Л. О. Проблеми вищої юридичної освіти та шляхи їх вирішення / Л. О. Стецюк [Електронний ресурс]. - Режим доступу: http://irbisnbuv.gov.ua/cgi-bin/irbis_nbuv;

15. Крупчан О. Д. До питання про якість юридичної освіти / О. Д. Крупчан // Правове регулювання економіки. 2013. - №13. - С. 48-52.
16. Сущенко В. М. Сучасні проблеми реформування юридичної освіти і науки в Україні / В. М. Сущенко // Наукові праці. наук.-метод. журнал. Політичні науки. Правознавство. - 2007, Том 69. Вип. 56 - С. 184-187.

17. Губанова Т.О. Основні проблеми практичної фахової підготовки юристів у коледжах як галузевих вищих навчальних закладах України / Т.О. Губанова // Порівняльно-аналітичне право. - 2016. - № 4. - С. 21 $-24$.

18. Пашковська Т. Юросвіта в Україні: правники дорікають на недопрацювання / Т. Пашковська // [Електронний ресурс]. Юридична Газета online - Peжим доступу: http://yurgazeta.com/publications/events/yurosvita-v-ukrayinipravniki-dorikayut-na-nedopracyuvannya.html.

19. Іншин М.I. Сутність і значення соціального забезпечення працівників поліції в сучасних умовах / M.I. Іншин // Вісник Чернівецького факультету Національного університету «Одеська юридична академія». - 2015. - № 4. - С. 268. - 277.

20. Чернєй В.В. Національна академія внутрішніх справ у контексті реалізації положень нового Закону України «Про вищу освіту» / В.В. Чернсй // Харківський національний університет внутрішніх справ в системі підготовки кадрів України : матеріали Всеукр. наук.-практ. конф., 26 верес. 2014 р. / МВС України, Харків. нац. ун-т внутр. справ. - Харків : ХНУВС, 2014. - C. $22-27$.

21. Черненко А.П. Європейський досвід підготовки поліцейських та можливість його використання в України / А.П. Черненко // Світовий досвід підготовки кадрів поліції та його впровадження в Україні : матер. Міжнар. наук.-практ. конф. (Дніпротеровськ, 17 бер. 2016 р.). -Дніпропетровськ : Дніпроп. держ. ун-т внутр. справ, 2016. - 566 с.

22. Smith A.T.H. Public Order Act and the offences against Public Order / A.T.H. Smith. - London. - 1997. $278 \mathrm{p}$.

23. Jurkanin T. J. A Statewide System of In-Service Training / T. J. Jurkanin . - Springfield, IL: Illinois Law Enforcement Training and Standards Board, 1998. - 359 p.

24. Illinois Law Enforcement Executive Institute. Macomb: Western Illinois University, 1999. - 268 p.

25. Паршикова A. Процедури підготовки поліцейських в країнах-членах $С С$ (навчальні заклади та програми, стандарти оцінки, законодавче регулювання) / А. Паршикова // Інформаційна довідка, підготовлена Європейським інформаційно-дослідницьким центром на запит народного депутата України. - інтернет Програми USAID «РАДА» 2015-2016 p.p.

26. Руг М. Юридические предметы в программе обучения Высшей школы полиции, современное состояние, перспективы развития / М. Руг // Проблемы развития образования, юридической науки и практики : материалы междунар. науч.-практ. конф., посвящ. 
45-летию Академии МВД Республики Беларусь / под общ. ред. И. И. Басецкого. - Минск, 2003.

27. Циганій С.О. Професійно-правова підготовка поліцейських в Україні та в зарубіжних країнах / С.О. Циганій // [Електронний ресурс]. - Режим доступу: $\quad$ file:///C:/Users/Serg/Downloads/10176-26346-1SM.pdf.
28. Лень В.В. До проблеми підготовки слідчих органів внутрішніх справ / В.В. Лень // Проблеми професійної підготовки слідчих : матер. наук.-практ. конф. (Дніпропетровськ, ДДУВС, 27 квітня 2007 р.). Дніпропетровськ, 2007. - С. 27-29.

Сергій Олексійович Павленко, кандидат юридичних наук, провідний науковий співробітник відділу організачії науково-дослідної роботи,

Володимир Геннадійович Севрук, кандидат юридичних наук, провідний науковий співробітник відділу організачії науково-дослідної роботи,

Свген Васильович Кобко, кандидат юридичних наук, дочент кафедри адміністративного права та прочесу, Начіональна академія внутрішніх справ, Солом'янська площа, 1, м. Киї, Україна

\section{ПІДГОТОВКА ПОЛІЕЙСЬКИХ В УМОВАХ РЕФОРМУВАННЯ СИСТЕМИ ОСВІТИ МВС УКРАЇНИ ВІДПОВІДНО ДО ЄВРОПЕЙСЬКИХ СТАНДАРТІВ}

Досліджено питання трансформації українських правоохоронних вищих навчальних закладів відповідно до сучасних європейських моделей і концепцій навчання поліцейських. При визначенні мети поліцейської освіти найбільш спірним залишається питання про те, чи давати працівникам поліції повноцінну освіту або ж готувати вузьких фахівців у конкретних областях поліцейської діяльності. Зазначається, що система навчання поліції в країнах Шенгенської угоди має свої відмінності і може бути відзначена відсутністю єдиного уніфікованого підходу через широкий спектр навчально-методичних концепцій. Зарубіжний досвід і передова практика в області правоохоронної освіти можуть стати ідеологічною платформою в ході українських реформ. Однак надмірна увага та намагання до перенесення на українські терени досвіду зарубіжних систем навчання і виховання працівників поліції не має достатньої аргументації, оскільки, як правило, не враховує національних особливостей, освітніх традицій та позитивних результатів у цій сфері. 3 огляду на це необхідно виважено поєднувати стандарти, закріплені у правових системах інших країн, з перевіреними практикою вітчизняними напрацюваннями в галузі освітнього процесу. Аргументовано, що підготовка поліцейських на базі навчальних планів юридичної освіти та освітнього рівня бакалавра та магістра є надбанням вітчизняної правоохоронної системи України. Тому під час розроблення Концепції щодо вдосконалення правничої (юридичної) освіти для фахової підготовки правника відповідно до стандартів СС особливу увагу слід приділяти правничим школам із специфічними умовами навчання, ураховуючи той факт, що одним із головних завдань поліції є охорона прав і свобод людини, а також інтересів суспільства і держави.

Ключові слова: підготовка, правоохоронні органи, реформування, поліція, освіта.

Submitted on June, 5, 2017

Reviewed by Doctor of Pedagogy, prof. Yu. Shcherbiak 